\title{
Hepatoblastom necesitând transplant hepatic. Prezentare de caz
}

\author{
Roxana-Cristina Mareş', Mihaela Chinceşan'1 Emoke Horvath², Horea Gozar ${ }^{3}$, \\ Cristina Oana Mărginean ${ }^{1}$ \\ ${ }^{1}$ Clinica Pediatrie I, Universitatea de Medicină, Farmacie, \\ Ştiinţe şi Tehnologie Tîrgu Mureş, România \\ ${ }^{2}$ Clinica de Anatomie Patologică, Universitatea de Medicină, Farmacie, \\ Ştiinţe şi Tehnologie Tîrgu Mureş, România \\ ${ }^{3}$ Clinica de Chirurgie şi Ortopedie Pediatrică, Universitatea de Medicină, Farmacie, Ştiinţe şi \\ Tehnologie Tîrgu Mureş, România
}

\begin{abstract}
REZUMAT
Hepatoblastomul este o patologie rară la pacienţii pediatrici, afectând 5-10/un milion de copii anual. Prezentăm cazul unui pacient în vârsta de doi ani care a fost internat în Clinica noastră pentru investigarea unei formaţiuni tumorale abdominale. Ecografia şi tomografia computerizată $(C T)$ au evidenţiat o tumoră hepatică solidă de dimensiuni mari, asociind tromboza venei porte drepte. Nivelul alfa-fetoproteinei serice (AFP) şi numărul de trombocite au fost mult crescute. Examinarea histopatologică a biopsiei hepatice a confirmat diagnosticul de hepatoblastom tip epitelial. Chimioterapia a fost iniţiată, urmată de o intervenţie chirurgicală în două etape: ligatura ramului portal drept şi rezecţia tumorală ulterioară. La şase luni după intervenţia chirurgicală o recidivă tumorală a fost suspectată, confirmată de examenul CT şi de nivelurile ridicate ale AFP. Pacientul a beneficiat de un transplant hepatic „de salvare“, cu evoluţie ulterioară favorabilă şi fără recădere de 3 ani.

Nivelurile crescute ale alfa-fetoproteinei şi trombocitoza sugerează diagnosticul de hepatoblastom. Transplan-

tul hepatic este opţiunea finală în cazul tumorilor inoperabile, de dimensiuni mari sau al recăderilor.
\end{abstract}

Cuvinte cheie: hepatoblastom, chimioterapie, recădere, transplant hepatic

Lista de abrevieri:

CT: Tomografie computerizată

AFP: Alfa-fetoproteina

Hgb: Hemoglobina

GOT: Aspartat-aminotransferaza

GPT: Alanin-aminotransferaza
LDH: lactat-dehidrogenaza

CRP: Proteina C-reactivă

VSH: viteza de sedimentare a hematiilor

HIV: Virusul imunodeficienţei umane

\section{INTRODUCERE}

Hepatoblastomul este o afecţiune malignă rară, reprezentând puţin peste $1 \%$ din totalul cancerelor pediatrice (1) şi afectând 5-10/un milion de copii pe an (2).

Etiologia bolii este necunoscută. Au fost puse în evidenţă multiple modificări genetice asociate cu diagnosticul de hepatoblastom, cele mai frecvente fiind trisomia 2, 8 şi 20 (3). Analiza genomului uman a condus la detectarea multor regiuni genomice modificate, dintre care câştigul de material genetic în regiunile $2 q$ 13-22, 2 q 36-37 şi deleţiile de $2 p$ şi $4 q$ au fost asociate cu tumori avansate şi prognostic slab $(3,4)$.

Diagnosticul de hepatoblastom este suspicionat în cazul pacienţilor cu vârsta cuprinsă între 6 luni şi 3 ani, în prezenţa unei tumori hepatice, a trombocitozei şi a unui nivel crescut al alfa-fetoproteinei serice (AFP) (3). Valorile crescute ale AFP trebuie interpretate în funcţie de vârstă, valori foarte ridicate fiind specifice cazurilor de hepatoblastom. Valorile moderat crescute pot fi detectate în tumorile de sac vitelin, în hepatocarcinom, precum şi în anumi- 
te tumori benigne (hamartom mezenchimal, hiperplazie nodulară focală şi hemangioendoteliom infantil) (4).

Clasificarea histologică a hepatoblastomului cuprinde şase tipuri grupate în două mari categorii: 1) hepatoblastom epitelial şi 2) hepatoblastom mixt epitelial şi mezenchimal. Tumorile epiteliale pure reprezintă aproximativ 56\% dintre cazuri; acestea sunt alcătuite din proporţii diferite de celule fetale şi celule embrionare. În cadrul acestui grup, tumorile fetale pure reprezintă $31 \%$, iar tumorile embrionare $19 \%$ dintre cazurile de hepatoblastom (5).

Tratamentul hepatoblastomului este relativ standardizat, singura controversă între grupurile de studiu Europene şi Americane rămâne momentul intervenţiei chirurgicale. Grupul European SIOPEL recomandă chimioterapia pre-chirurgicală urmată de excizia tumorii şi apoi o perioadă scurtă de chimioterapie post-chirurgicală (6). Grupul de studiu American recomandă intervenţia chirurgicală în momentul diagnosticului (aplicabilă la 50\% dintre pacienţi) urmată de chimioterapia post-chirurgicală (7).

Prezentăm cazul unui pacient cu diagnosticul de hepatoblastom cu o evoluție nefavorabilă și subliniem importanţa transplantului hepatic în managementul acestor cazuri.

Consimţământul informat al mamei pacientului a fost obţinut anterior publicării acestei prezentări de caz.

\section{PREZENTARE DE CAZ}

\section{Anamneză}

Un pacient de sex masculin, în vârstă de 2 ani, a fost internat în clinica noastră pentru investigarea unei formaţiuni tumorale abdominale. Antecedentele heredo-colaterale şi personale nu au evidenţiat elemente patologice semnificative.

\section{Examen clinic}

Examenul clinic la internare a evidenţiat o stare generală influenţată, întârzierea creşterii staturoponderale (greutate $=7,9 \mathrm{~kg}<$ percentila 3, înălţime $=75 \mathrm{~cm}<$ percentila 3 ), paloare tegumentară marcată, abdomenul destins cu o masă tumorală fermă în flancul drept.

\section{Diagnostic pozitiv}

Rezultatele analizelor de laborator au pus în evidenţă anemie (Hgb: 9,5 g/dl), leucocitoză (24.900/ $\left.\mathrm{mm}^{3}\right)$, neutrofilie $\left(16.000 / \mathrm{mm}^{3}\right)$, trombocitoză $\left(994.000 / \mathrm{mm}^{3}\right)$, modificări de transaminaze (GOT$240 \mathrm{U} / 1), \mathrm{LDH}(618 \mathrm{U} / \mathrm{l})$ şi markeri inflamatori crescuţi (PCR-104,56 mg/dl, VSH-65 mm/h).
Ecografia abdominală efectuată a evidenţiat o tumoră hepatică solidă. Examenul CT a descris o tumoră de dimensiuni mari, 59/69/55 mm, localizată în segmentul 6, cu structură eterogenă şi zone de necroză, aderentă la muşchiul oblic extern şi cu tromboza venei porte drepte, fără leziuni metastatice pulmonare, rinichi în potcoavă (Fig. 1).

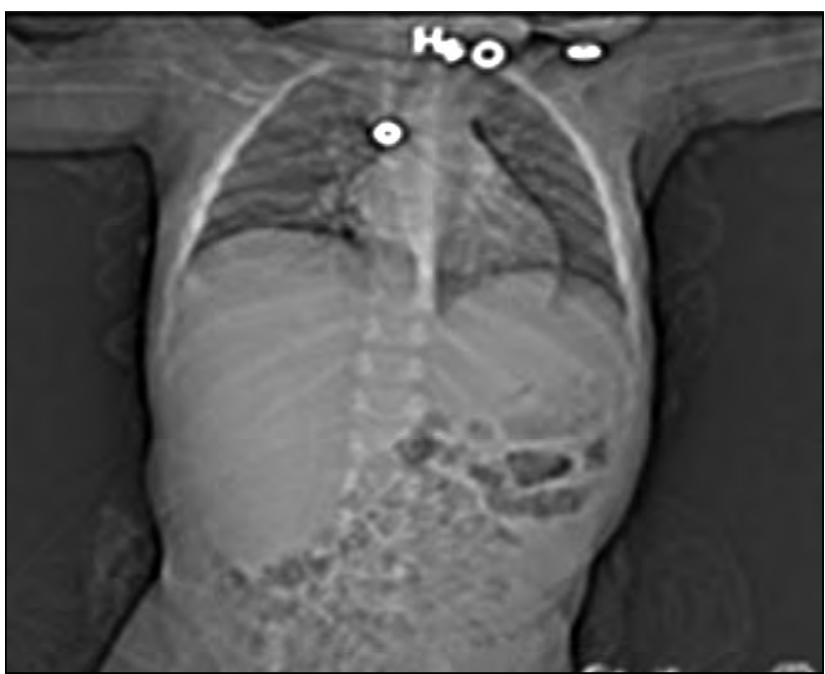

FIGURA 1. CT abdominal - tumoră hepatică de dimensiuni mari

Am exclus o infecţie cu virus hepatic B, C, HIV, Toxoplasma gondii, virusul Epstein-Barr sau citomegalovirus. Nivelurile de acid vanil-mandelic în urină au fost determinate pentru a exclude diagnosticul de neuroblastom, cu o valoare normală: 1,11 $\mathrm{mg} / 24 \mathrm{~h}$.

Valoarea AFP a fost mult crescută $-174.200 \mathrm{UI} /$ $\mathrm{ml}$ (Normal: 0,92-6,73).

Având în vedere vârsta pacientului, nivelul crescut al AFP, trombocitoza şi datele imagistice, am ridicat suspiciunea de hepatoblastom. A fost efectuată o biopsie hepatică, iar examinarea histopatologică a confirmat diagnosticul de hepatoblastom tip epitelial (Fig. 2).

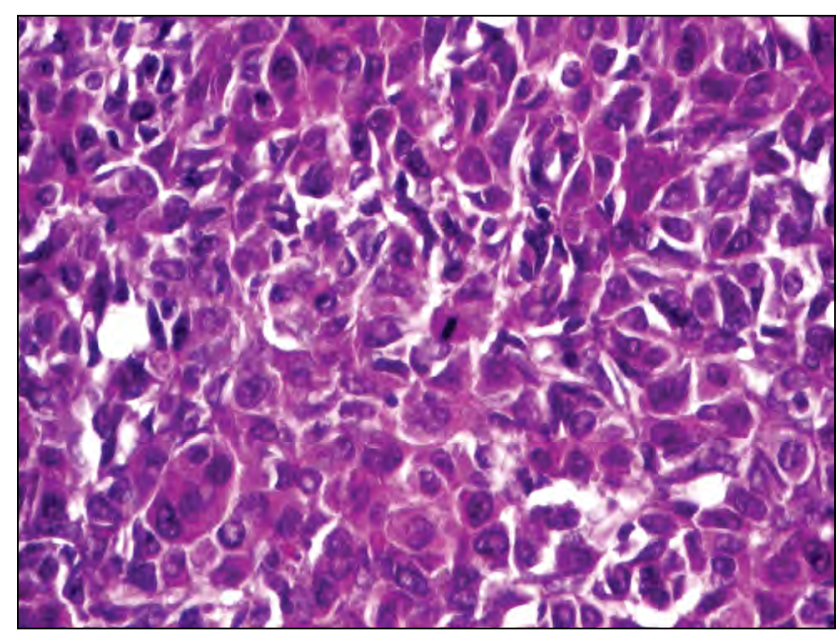

FIGURA 2. Hepatoblastom. Hematoxilină-eozină 


\section{Tratament}

Odată ce diagnosticul de hepatoblastom - high risk (din cauza afectării venei porte) a fost confirmat s-a iniţiat chimioterapia, conform ghidului International Childhood Liver Tumors Strategy Group 3HR, care a implicat 4 cicluri de Cisplatin şi 4 cicluri de Carboplatin-Doxorubicin. Secundar chimioterapiei pacientul a dezvoltat aplazie medulară ce a necesitat transfuzii de sânge şi factor de stimulare a coloniilor de granulocite.

Valorile AFP au scăzut la 29,9 ng/ml, iar examenul CT abdominal a evidenţiat o scădere în dimensiuni a tumorii, de 60/32/54 mm.

Prima intervenţie chirurgicală a fost reprezentată de ligatura ramului drept al venei porte, urmată de un ciclu de Cisplatin. Etapa a doua a procedurii chirurgicale (rezecţia tumorală) a fost efectuată cinci luni mai târziu urmată de un ciclu final de Cisplatin.

\section{Evoluție şi complicații}

La şase luni după a doua intervenţie chirurgicală s-a suspicionat o recidivă din cauza apariţiei hepatomegaliei, confirmată de niveluri foarte crescute ale alfa-feto proteinei $(56.8163 \mathrm{UI} / \mathrm{ml})$ şi examenul CT abdominal care a evidenţiat leziuni multiple în lobii hepatici drept şi stâng. Chimioterapia a fost reluată, cu 3 cicluri de Carboplatin-Doxorubicin şi 4 cicluri de Cisplatin/Vincristin/5-Fluorouracil. Scintigrafia osoasă şi examenul CT toracic nu au evidenţiat metastaze toracice sau osoase.

Urmând protocolul pentru recădere după intervenţii chirurgicale şi chimioterapie, a fost efectuat un transplant ortotopic hepatic cu segmente 2-3 de la un donator viu înrudit. Evoluţia postoperatorie a grefei a fost favorabilă şi pacientul nu a prezentat recădere de trei ani.

Pentru a evalua gradul de fibroză al ficatului transplantat, am efectuat elastografie hepatică şi Fibrotest ${ }^{\circledR}$, ambele investigaţii fiind în limite normale.

\section{DISCUȚII}

Un număr mare de sindroame şi malformaţii congenitale au fost descrise la pacienţii cu hepatoblastom, cum ar fi sindromul Beckwith-Wiedemann, polipoza adenomatoasă familială şi malformaţiile renale. S-a constatat că această boală este mai frecventă în cazul sugarilor născuţi prematur sau cu greutate mica la naştere $(8,9)$. Pacientul nostru nu a prezentat niciunul dintre factorii de risc menţionaţi mai sus ca fiind asociaţi cu o incidenţă crescută a hepatoblastomului. În ceea ce priveşte posibilele boli asociate, el a prezentat rinichi în potcoavă cu hipoplazia rinichiului drept. Chan și colaboratorii au propus o asociere posibilă între cazurile de hepatoblastom şi hipoplazia renală într-un studiu retrospectiv efectuat în Spitalul de Oncologie Los Angeles, raportând trei asemenea cazuri (10).

Prognosticul cazurilor de hepatoblastom depinde de extensia tumorii în momentul diagnosticului, de posibilitatea de excizie şi de tipul histologic $(11,12)$. În cazul nostru, implicarea venei porte şi dimensiunile mari ale tumorii au condus la includerea cazului în stadiul III, neuroblastom iniţial inoperabil. În ceea ce priveşte histologia, tipul fetal pur conferă cel mai bun prognostic (13). Cazul nostru a prezentat o histologie mixtă epitelială, embrionară şi fetală, cu un prognostic mai puţin favorabil.

Tratamentul hepatoblastomului combină chimioterapia preoperatorie cu excizia chirurgicală, permiţând o rată de supravieţuire de peste $70 \%$ (14). Rezecţia chirurgicală completă este piatra de temelie a tratamentului; cu toate acestea, mai puţin de $40 \%$ dintre pacienţi au tumori excizabile în momentul diagnosticului (15). Dacă tumora este considerată inoperabilă şi pacientul prezintă un risc crescut de complicaţii, biopsia şi chimioterapia preoperatorie sunt indicate (5).

Asmar şi Rassi au publicat cazul unui sugar de sex feminin în vârstă de 8 luni, care a prezentat un hepatoblastom mixt epitelial şi mezenchimal neresponsiv la tratamentul chimioterapic, dar care a fost tratat cu succes prin rezecţie chirurgicala, fiind fără recidivă după 15 ani (16).

Contraindicaţiile operatorii sunt: tumora de dimensiuni mari, implicând riscul de hemoragie severă; afectarea mai multor lobi hepatici; afectarea venei hepatice sau venei cave inferioare (17). În cazul nostru am optat pentru o procedură în două etape: în prima etapă a fost realizată ligatura ramului portal drept. Această manevră a produs o fibroză a lobului hepatic drept şi o creştere în dimensiuni a lobului hepatic stâng. În aceste condiţii, în timpul celei de-a doua etape, o rezecţie a tumorii în ţesutul fibros a fost mai uşor de efectuat şi riscul de hemoragie a fost scăzut. Această tehnică efectuată asupra unui pacient pediatric a fost descrisă pentru prima data în studiul lui Chan şi colaboratorii. Aceştia au efectuat ligatura de venă portă şi partiţionarea hepatică urmată de rezecţia tumorală ulterioară unei paciente în vârstă de 6 ani la care s-a decelat un hepatoblastom gigant. Pacienta a prezentat o evoluţie favorabilă comparativ cu pacientul nostru, care 
a prezentat recidivă după 6 luni (18). Un alt studiu efectuat de Qazi şi colaboratorii a descris însă un caz de recidivă tumorală precoce la un sugar diagnosticat cu hepatoblastom, care a dezvoltat recurenţa bolii în prima lună după operaţia etapizată (ligatura de venă portă şi rezecţia tumorală ulterioară) (19).

În ciuda chimioterapiei agresive şi a rezecţiei complete a tumorii, pacientul nostru a prezentat o recădere tumorală la 6 luni după intervenţia chirurgicală, cu leziuni multiple în lobii hepatici drept şi stâng. Transplantul hepatic ,de salvare“ a fost singura opţiune viabilă. A fost efectuat un transplant ortotopic hepatic cu segmente 2-3 de la un donator viu (mama), cu o evoluție favorabilă postoperatorie şi pe termen lung. Fernandez şi colaboratorii au raportat un caz de hepatoblastom chimiorezistent la un pacient cu trisomie 18 , care a dezvoltat o recădere după tratamentul chirurgical şi chimioterapie cu Cisplatin, Vincristin şi 5-Fluorouracil. Similar cazului nostru, pacientului i s-a efectuat un transplant hepatic ortotopic, cu evoluţie ulterioară favorabilă (20).

Transplantul hepatic de primă intenţie este indicat în cazul hepatoblastoamelor multifocale sau solitare care invadează toate cele patru sectoare ale ficatului sau în cazul tumorilor localizate central, în imediata apropiere a vaselor mari hepatice. Transplantul hepatic pare să aibă un rezultat mai bun

\section{BIBLIOGRAFIE}

1. Zhang J, Xu F, Chen $\mathrm{K}$ et al. An effective approach for treating unresectable hepatoblastoma in infants and children: Pre-operative transcatheter arterial chemoembolization. Oncol Lett. 2013; 6(3): 850- 854 .

2. Khaderi S, Guiteau J, Cotton RT et al. Role of liver transplantation in the management of hepatoblastoma in pediatric population. World $\mathrm{J}$ Transplant. 2014; 24; 4(4): 294- 298.

3. Perilongo G, Shafford EA. Liver tumors. Eur J Cancer. 1999; 35: 953-959.

4. Schnater JM, Kohler SE, Lamers WH et al. Where do we stand with hepatoblastoma? A review. Cancer. 2003; 98: 668-678.

5. Finegold MJ, Lopez-Terrada DH, Bowen J et al. Protocol for the examination of specimens from pediatric patients with hepatoblastoma. Arch Pathol Lab Med. 2007; 131: 520-529.

6. Perilongo G, Shafford E, Maibach R et al. International Society of Paediatric Oncology - SIOPEL 2. Risk-adapted treatment for childhood hepatoblastoma; final report of the second study of the International Society of Paediatric Oncology - SIOPEL 2. Eur J Cancer. 2004; 40: 411-421.

7. Ortega JA, Douglass EC, Feusner JH et al. Randomized comparison of cisplatin/ vincristine/5-fluorouracil and cisplatin/continuous infusion Doxorubicin for the treatment of pediatric hepatoblastoma (HB): A report from the Children's Cancer Group and the Pediatric Oncology Group. J Clin Oncol. 2000; 18: 2665-2675.

8. Von Schweinitz D. Hepatoblastoma: Recent developments in research and treatment. Seminars in Pediatric Surgery. 2012;21:21-30. atunci când este efectuat ca o procedură de primă intenţie, mai degrabă decât o procedură de salvare în cazul bolii recurente. Otte et al. au raportat o supravieţuire de $85 \%$ pentru 7 copii care au suferit transplant hepatic primar şi doar $40 \%$ pentru 5 copii la care s-a efectuat un transplant „de salvare“ (21).

Elastografia hepatică poate fi utilizată pentru a detecta neinvaziv dezvoltarea fibrozei în ficatul transplantat, cu o sensibilitate şi specificitate bună (22). Am efectuat elastografie shear-wave pentru a evalua gradul de fibroză hepatică la pacientul nostru şi am comparat-o cu rezultatul Fibrotest ${ }^{\circledR}$ (un algoritm dezvoltat de Biopredictive ca o alternativă la biopsia hepatică, care utilizează nivelele serice ale alfa-2 macroglobulinei, haptoglobinei, apolipoproteinei A1, bilirubinei totale şi gamma-glutamiltranspeptidazei). Ambele investigaţii au fost în intervalul normal, indicând lipsa fibrozei hepatice.

\section{CONCLUZII}

Hepatoblastomul este o patologie foarte rară la copii. Valorile crescute ale alfa-fetoproteinei şi ale trombocitelor indică diagnosticul de hepatoblastom. Pentru pacienţii cu tumori extinse, non-rezecabile sau cu recăderi ale bolii după chimioterapie şi intervenţie chirurgicală, transplantul hepatic rămâne opţiunea finală, salvatoare.

Conflict of interest: none declared Financial support: none declared

9. Paquette $\mathrm{K}$, Coltin $\mathrm{H}$, Boivin A et al. Cancer risk in children and young adults born preterm: A systematic review and meta-analysis. PloS One. 2019; 14(1): e0210366.

10. Chan R, Mascarenhas L, Venkatramani R. Hepatoblastoma and hypoplastic kidneys: a new association. Pediatr Blood Cancer. 2014;61(8):1476-8.

11. Stocker JT. Hepatic tumor in children. In: Suchy FJ, Sokol RJ, Balistreri WF, editors. Liver disease in children. 2nd edition. Lippincott Williams \& Wilkins; 2001. 91: 5-49.

12. Herzog CE, Andrassy RJ, Eftekhari F. Childhood Cancers: Hepatoblastoma. The Oncologist. 2000;5:445-453.

13. Carceller A, Blanchard $H$, Champagne $J$ et al. Surgical resection and chemotherapy improve survival rate for patients with hepatoblastoma. J Pediatr Surg. 2001; 36: 755-759.

14. Ang JP; Heath JA, Donath S et al. Treatment outcomes for hepatoblastoma: an institution's experience over two decades. Pediatr Surg Int. 2007; 23(2):103-9.

15. Teran DA, Beltran OG, Bru RC et al. Efficacy of neoadjuvant therapy and surgical rescue for locally advanced hepatoblastomas: 10 year single-center experience and literature review. World J Gastroenterol. 2014; 20(29): 10137-10143.

16. Suk-Bae M, Hyun-Baek S, Jeong-Meen S et al. Hepatoblastoma: 15 -year experience and role of surgical treatment. J Korean Surg Soc. 2011;81:134-140.

17. El Asmar A, El Rassi Z. Hepatoblastoma in childhood, long term survival achieved: 2 case reports and literature review. Int J Surg Case Rep. 2016; 21: 55-58. 
18. Chan A, Chung P, Poon R. Little girl who conquered the "ALPPS", World J Gastroenterol. 2014; 20(29): 10208-10211.

19. Qazi A, Syed A, Khan AW et al. Early multifocal recurrence of hepatoblastoma in the residual liver after R0 liver resection with ALPPS procedure: a case report. Ann Transl Med. 2016; 4(19): 375.

20. Fernandez KS, Baum R, Fung B et al. Chemoresistant hepatoblastoma in a patient with mosaic trisomy 18 treated with orthotopic liver transplantation. 2011; Pediatric Blood \& Cancer 56(3):498-500
21. Otte JB, Pritchard J, Aronson DC Brown J, Czauderna P, Maibach R et al. Liver transplantation for hepatoblastoma: results from the International Society of Pediatric Oncology (SIOP) study SIOPEL-1 and review of the world experience. Pediatr Blood Cancer 2004; 42:74-83.

22. Perry MT, Savjani N, Bluth El et al. Point Shear Wave Elastography in Assessment of Hepatic Fibrosis: Diagnostic Accuracy in Subjects With Native and Transplanted Livers Referred for Percutaneous Biopsy. Ultrasound Q. 2016; 32(3):201-7 